\title{
PENINGKATAN PEMAHAMAN KARYAWAN PT ASIA FORESTAMA RAYA MENGENAI PERLINDUNGAN HAK-HAK TENAGA KERJA KONTRAK BERDASARKAN UNDANG-UNDANG NOMOR 13 TAHUN 2003 TENTANG KETENAGAKERJAAN
}

\author{
Suhendro ${ }^{1}$, Andrew Shandy Utama ${ }^{2}$, Ade Pratiwi Susanty ${ }^{3}$ \\ 1) Fakultas hukum Universitas Lancang Kuning \\ Email : suhendroadvokat@yahoo.com
}

\begin{abstract}
ABSTRAK
Permasalahan mitra dalam kegiatan pengabdian kepada masyarakat ini adalah minimnya pemahaman karyawan PT Asia Forestama Raya mengenai perlindungan hakhak tenaga kerja kontrak berdasarkan Undang-Undang Nomor 13 Tahun 2003 tentang Ketenagakerjaan. Solusi yang ditawarkan dalam kegiatan pengabdian kepada masyarakat ini adalah peningkatan pemahaman karyawan PT Asia Forestama Raya mengenai perlindungan hak-hak tenaga kerja kontrak berdasarkan Undang-Undang Nomor 13 Tahun 2003 tentang Ketenagakerjaan. Metode pelaksanaan yang digunakan dalam kegiatan pengabdian kepada masyarakat ini adalah dengan menggunakan metode ceramah, dialog, dan diskusi dalam rangka memberikan penyuluhan hukum Kesimpulannya bahwa kegiatan ini telah berhasil dilaksanakan dan manfaatnya dapat dirasakan langsung oleh para peserta. Hal ini dapat dilihat dari jawaban para peserta pada kuisioner yang diberikan setelah kegiatan dilaksanakan. Dari 31 orang peserta, $83,2 \%$ menjawab telah memahami materi yang disampaikan.
\end{abstract}

Kata kunci: Hukum, Hak Tenaga Kerja Kontrak

\begin{abstract}
The problem of partners in community service activities is the lack of understanding of PT Asia Forestama Raya employees regarding the protection of contract labor rights based on Law Number 13 of 2003 concerning Labor. The solution offered in this community service activity is to increase the understanding of PT Asia Forestama Raya employees regarding the protection of contract labor rights based on Law Number 13 of 2003 concerning Labor. The implementation method used in community service activities is to use lecture, dialogue and discussion methods in order to provide legal counseling. The conclusion is that this activity has been successfully implemented and the benefits can be felt directly by the participants. This can be seen from the answers of the participants in the questionnaire given after the activity was carried out. Of the 31 participants, 83,2\% answered that they understood the material presented..
\end{abstract}

Key word: Law, Contract Labor Right 


\section{PENDAHULUAN}

Pembangunan ketenagakerjaan sebagai bagian integral dari pembangunan nasional berdasarkan Pancasila dan Undang-Undang Dasar Negara Republik Indonesia Tahun 1945, dilaksanakan dalam rangka pembangunan manusia Indonesia seutuhnya dan pembangunan masyarakat Indonesia seluruhnya untuk meningkatkan harkat, martabat, dan harga diri tenaga kerja serta mewujudkan masyarakat sejahtera, adil, makmur, dan merata, baik materiil maupun spiritual.

Pembangunan ketenagakerjaan harus diatur sedemikian rupa sehingga terpenuhi hak-hak dan perlindungan yang mendasar bagi tenaga kerja, serta pada saat yang bersamaan dapat mewujudkan kondisi yang kondusif bagi pengembangan dunia usaha.

Pembangunan ketenagakerjaan mempunyai banyak dimensi dan keterkaitan. Keterkaitan itu tidak hanya dengan kepentingan tenaga kerja selama, sebelum, dan sesudah masa kerja, tetapi juga keterkaitan dengan kepentingan pengusaha, pemerintah, dan masyarakat. Untuk itu, diperlukan pengaturan yang menyeluruh dan komprehensif, antara lain mencakup pengembangan sumber daya manusia, peningkatan produktivitas dan daya saing tenaga kerja Indonesia, upaya perluasan kesempatan kerja, pelayanan penempatan tenaga kerja, dan pembinaan hubungan industrial.

Undang-Undang Dasar Negara Republik Indonesia Tahun 1945 mengamanatkan bahwa tiap-tiap warga negara berhak atas pekerjaan dan penghidupan yang layak bagi kemanusiaan. Sejalan dengan itu, Undang-Undang Nomor 13 Tahun 2003 tentang Ketenagakerjaan menegaskan bahwa setiap tenaga kerja memiliki kesempatan yang sama tanpa diskriminasi untuk memperoleh pekerjaan. Oleh karena itu, perlindungan terhadap hak-hak tenaga kerja merupakan tanggung jawab negara. Selain itu, perlindungan terhadap hak-hak tenaga kerja perlu terus disosialisasikan mengingat tidak semua tenaga kerja yang mengetahui hukum pada umumnya dan khususnya UndangUndang Nomor 13 Tahun 2003 tentang Ketenagakerjaan.

Dalam rangka melindungi hak-hak tenaga kerja, Undang-Undang Nomor 13 Tahun 2003 tentang Ketenagakerjaan memberikan hak kepada tenaga kerja untuk membentuk serikat pekerja. Fungsi serikat pekerja adalah sebagai pihak dalam pembuatan Perjanjian Kerja Bersama dan penyelesaian perselisihan perburuhan; sebagai wakil dalam lembaga kerja sama; sebagai sarana menciptakan hubungan industrial yang harmonis, dinamis, dan berkeadilan; sebagai sarana penyalur aspirasi; sebagai perencana, pelaksana, dan penanggung jawab pemogokan buruh; serta sebagai wakil dalam memperjuangkan kepemilikan saham. Akan tetapi, dengan alasan berbagai kesibukan dan keterbatasan, serikat pekerja tidak ada memberikan sosialisasi mengenai perlindungan terhadap hak-hak tenaga kerja. Serikat pekerja biasanya baru aktif pada saat terjadinya sengketa antara perusahaan dan tenaga kerjanya. Mengingat tidak semua tenaga kerja yang mengetahui hukum, khususnya Undang-Undang Nomor 13 Tahun 2003 tentang Ketenagakerjaan, maka dosen harus turun ke masyarakat untuk memberikan penyuluhan dan berbagi ilmu pengetahuan yang dimilikinya sebagai bagian dari implementasi Tri Dharma perguruan tinggi.

Khalayak sasaran kegiatan pengabdian kepada masyarakat ini adalah karyawan PT Asia Forestama Raya. Dari observasi awal dan wawancara yang dilakukan dengan Manajer PT Asia Forestama Raya, diketahui bahwa saat ini lebih kurang 90\% karyawan PT Asia Forestama Raya merupakan karyawan kontrak. Selain itu, Manajer Operasional PT Asia Forestama Raya juga menjelaskan bahwa setiap tahun sering terjadi permasalahan antara perusahaan dan karyawan mengenai hak-hak karyawan dikarenakan ketidaktahuan karyawan PT Asia Forestama Raya terhadap hak-hak 
mereka sebagai tenaga kerja kontrak berdasarkan Undang-Undang Nomor 13 Tahun 2003 tentang Ketenagakerjaan.

Berdasarkan analisis situasi di atas, maka yang menjadi permasalahan mitra dalam kegiatan pengabdian kepada masyarakat ini adalah minimnya pemahaman karyawan PT Asia Forestama Raya mengenai perlindungan hak-hak tenaga kerja kontrak berdasarkan Undang-Undang Nomor 13 Tahun 2003 tentang Ketenagakerjaan.

\section{TINJAUAN PUSTAKA}

Tujuan pokok hukum ketenagakerjaan adalah melaksanakan keadilan sosial dalam perburuhan dengan melindungi buruh terhadap kekuasaan yang tidak terbatas dari pihak majikan agar bertindak sesuai dengan kemanusiaan. Buruh dan majikan diberi kebebasan untuk mengadakan peraturan tertentu karena hukum perburuhan bersifat otonomi, tetapi peraturan ini tidak boleh bertentangan dengan peraturan pemerintah yang bermaksud mengadakan perlindungan terhadap buruh. ${ }^{1}$

Secara umum, terdapat dua sifat hukum ketenagakerjaan, yaitu sebagai berikut:

1. Hukum yang bersifat mengatur.

2. Hukum yang bersifat memaksa. ${ }^{2}$

Hakikat hukum ketenagakerjaan adalah melindungi pekerja dari tindakan sewenang-wenang pihak pengusaha. Secara yuridis, kedudukan pekerja dan pengusaha itu sama. Secara sosial ekonomi, kedudukan pekerja lebih rendah dari pengusaha. Oleh karena itu, diperlukan pemberdayaan dan proses kemitraan dalam bekerja yang dilindungi oleh undang-undang. ${ }^{3}$

Secara yuridis, buruh memiliki kebebasan yang dilindungi oleh peraturan perundang-undangan yang berlaku. Artinya, buruh memiliki kedudukan yang sama di depan hukum dengan majikan, tetapi secara sosiologis, kedudukan buruh tersubordinasi oleh majikan yang artinya majikan memiliki kewenangan untuk memerintah buruh dan menetapkan syarat-syarat kerja dan keadaan perburuhan. Dengan kata lain, kedudukan majikan lebih tinggi daripada kedudukan buruh dalam hubungan perburuhan. Secara sosiologis, buruh adalah orang yang tidak memiliki bekal hidup selain dari tenaganya itu, ia terpaksa bekerja pada orang lain, dan majikan inilah yang menentukan syaratsyarat diterima atau tidaknya buruh bekerja. Dengan demikian, kedudukan majikan lebih dominan daripada pekerja atau buruh, tetapi bukan berarti majikan bebas memperlakukan pekerja sebagaimana melakukan perbudakan dan memeras tenaganya tanpa mengikuti peraturan perundangan yang berlaku. Oleh karena itu, antara buruh dan majikan memerlukan perjanjian kerja yang mengatur pola kerja dan pola pengupahannya. ${ }^{4}$

Secara teoritis, terdapat tiga jenis perlindungan kerja, yaitu sebagai berikut:

1. Perlindungan sosial, yaitu perlindungan yang berkaitan dengan usaha kemasyarakatan, yang memungkinkan pekerja/buruh mengenyam dan mengembangkan kehidupannya sebagaimana manusia pada umumnya, khususnya sebagai anggota masyarakat dan anggota keluarga. Perlindungan sosial disebut juga dengan kesehatan kerja.

2. Perlindungan teknis, yaitu jenis perlindungan yang berkaitan dengan usaha-usaha untuk menjaga agar pekerja/buruh terhindar dari bahaya kecelakaan yang 
ditimbulkan oleh alat-alat kerja atau bahan yang dikerjakan. Perlindungan ini lebih sering disebut sebagai keselamatan kerja.

3. Perlindungan ekonomis, yaitu jenis perlindungan yang berkaitan dengan usahausaha untuk memberikan kepada pekerja/buruh suatu penghasilan yang cukup untuk memenuhi keperluan sehari-hari baginya dan keluarganya, termasuk dalam hal pekerja/buruh tidak mampu bekerja karena sesuatu di luar kehendaknya. Perlindungan jenis ini biasanya disebut dengan jaminan sosial. ${ }^{5}$

\section{METODE PELAKSANAAN}

Metode pelaksanaan kegiatan pengabdian kepada masyarakat ini adalah dengan menggunakan metode ceramah, dialog, dan diskusi dalam rangka penyuluhan hukum tentang peningkatan pemahaman karyawan PT Asia Forestama Raya mengenai perlindungan hak-hak tenaga kerja kontrak berdasarkan Undang-Undang Nomor 13 Tahun 2003 tentang Ketenagakerjaan.

Metode pendekatan yang ditawarkan untuk menyelesaikan permasalahan mitra dalam kegiatan pengabdian kepada masyarakat ini adalah dengan melakukan observasi awal ke PT Asia Forestama Raya guna menggali beberapa informasi mengenai kondisi karyawan. Setelah itu, melakukan wawancara dengan Manajer Operasional PT Asia Forestama Raya guna mencari tahu permasalahan yang sering dihadapi oleh karyawannya.

Partisipasi mitra dalam kegiatan pengabdian kepada masyarakat ini yaitu Manajer Operasional PT Asia Forestama Raya berkontribusi menyediakan waktu, menyediakan tempat beserta fasilitas pendukungnya, dan menghadirkan karyawan sebagai peserta kegiatan.

Evaluasi pelaksanaan kegiatan pengabdian kepada masyarakat ini dilakukan dengan membagikan kuisioner sebelum dan sesudah kegiatan dilaksanakan untuk mengukur tingkat pengetahuan masyarakat. Keberhasilan pelaksanaan kegiatan pengabdian kepada masyarakat ini diukur dari antusias para peserta yang mengikuti kegiatan, adanya pertanyaan yang diajukan oleh para peserta, serta jawaban para peserta pada kuisioner yang telah dibagikan sebelum dan sesudah kegiatan dilaksanakan.

\section{HASIL DAN PEMBAHASAN}

Kegiatan pengabdian kepada masyarakat ini dilaksanakan pada hari Kamis tanggal 13 Desember 2018 dimulai pukul 14.00 WIB sampai dengan selesai di aula PT Asia Forestama Raya yang beralamat di Jl. RGM, Rumbai Pesisir. Kegiatan pengabdian kepada masyarakat ini dihadiri sebanyak 31 (tiga puluh satu) orang peserta. Pelaksanaan kegiatan pengabdian kepada masyarakat ini berjalan dengan lancar karena judul yang diangkat sesuai dengan permasalahan mitra dan kebutuhan para peserta.

Sikap khalayak sasaran selama pelaksanaan kegiatan pengabdian kepada masyarakat ini adalah baik dan antusias dalam memperhatikan materi yang dipaparkan oleh tim pelaksana. Hal ini didukung oleh Manajer Operasional PT Asia Forestama Raya yang memfasilitasi kegiatan dengan menyediakan waktu, tempat, dan fasilitas pendukung lainnya.

Selain meningkatkan pemahaman karyawan PT Asia Forestama Raya mengenai perlindungan hak-hak tenaga kerja kontrak berdasarkan Undang-Undang Nomor 13 Tahun 2003 tentang Ketenagakerjaan, hasil fisik yang bermanfaat bagi para peserta 
adalah memperoleh materi yang diberikan oleh tim pelaksana dalam bentuk fotokopi hand out materi.

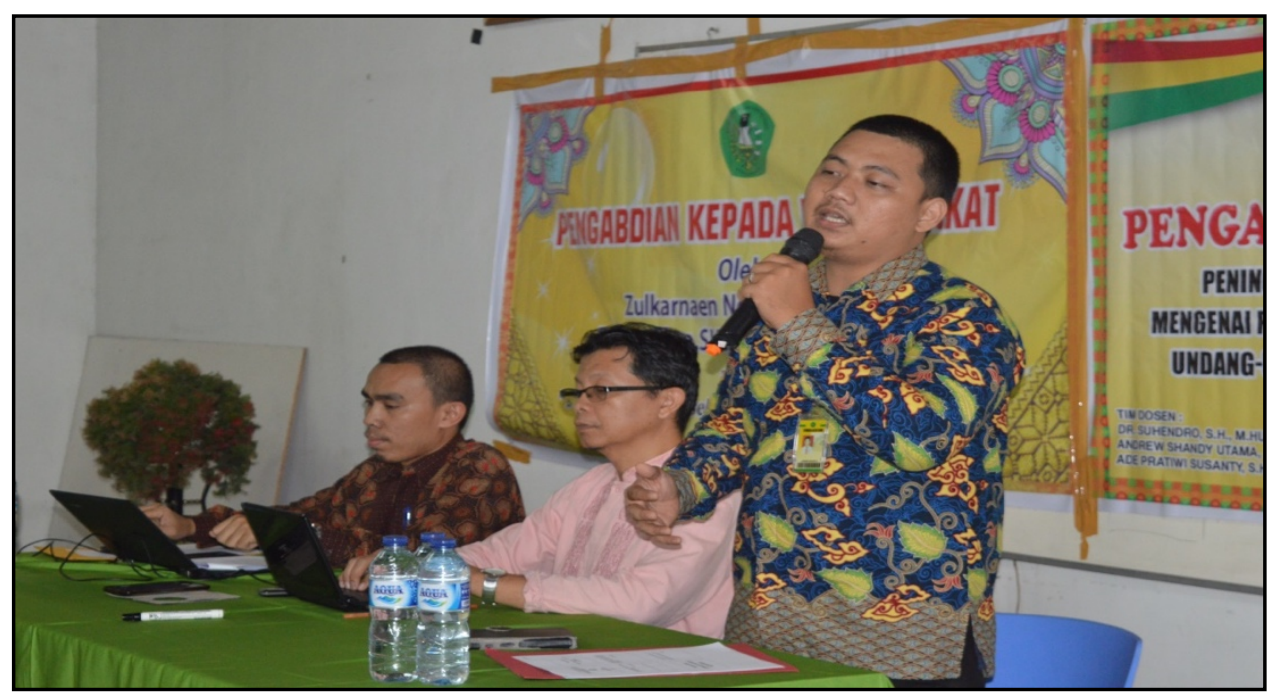

Gambar 1. Pemaparan Materi

Untuk mengetahui sejauh mana tingkat pengetahuan para peserta mengenai materi yang akan disampaikan, maka sebelum pelaksanaan kegiatan, tim pelaksana membagikan kuisioner untuk langsung diisi oleh para peserta. Selanjutnya, untuk mengatahui keberhasilan dari pelaksanaan kegiatan pengabdian kepada masyarakat ini, maka tim pelaksana kembali membagikan kuisioner kepada para peserta setelah kegiatan dilaksanakan.

Pelaksanaan kegiatan pengabdian kepada masyarakat ini dapat dikatakan telah berhasil dilaksanakan dan manfaatnya dapat dirasakan langsung oleh para peserta, yaitu meningkatkan pemahaman karyawan PT Asia Forestama Raya mengenai perlindungan hak-hak tenaga kerja kontrak berdasarkan Undang-Undang Nomor 13 Tahun 2003 tentang Ketenagakerjaan. Hal ini dapat dilihat dari jawaban para peserta pada kuisioner yang diberikan sebelum dan setelah kegiatan dilaksanakan. Sebelum kegiatan dilaksanakan, dari 31 orang peserta, hanya 10,3\% yang menjawab telah mengetahui mengenai materi yang akan disampaikan. Sedangkan, setelah kegiatan dilaksanakan, $83,2 \%$ peserta menjawab telah mengetahui materi yang disampaikan.

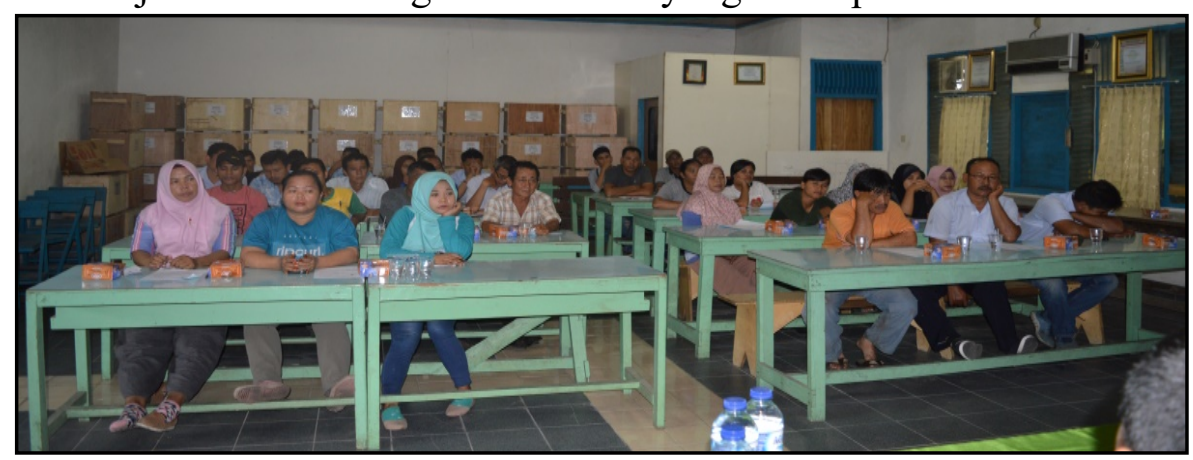

Gambar 2. Peserta Pengabdian

Pada kegiatan pengabdian kepada masyarakat ini, tim pelaksana memaparkan materi mengenai perlindungan hak-hak tenaga kerja kontrak berdasarkan UndangUndang Nomor 13 Tahun 2003 tentang Ketenagakerjaan. Menurut undang-undang tersebut, yang menjadi hak-hak bagi tenaga kerja kontrak adalah sebagai berikut: 
1. Perlakuan yang sama tanpa diskriminasi. (Pasal 6)

2. Pelatihan kerja. (Pasal 12 Ayat 3)

3. Penempatan kerja. (Pasal 31)

4. Tidak ada masa percobaan. (Pasal 58 Ayat 1)

5. Waktu kerja. (Pasal 77 Ayat 2)

6. Waktu kerja lembur. (Pasal 78 Ayat 1)

7. Upah kerja lembur. (Pasal 78 Ayat 2)

8. Waktu istirahat dan cuti. (Pasal 79 Ayat 2)

9. Waktu untuk beribadah wajib. (Pasal 80)

10. Tenaga kerja perempuan yang haid. (Pasal 81 Ayat 1)

11. Tenaga kerja perempuan yang melahirkan. (Pasal 82)

12. Tenaga kerja perempuan yang menyusui. (Pasal 83)

13. Perlindungan atas keselamatan dan kesehatan kerja. (Pasal 86 Ayat 1)

14. Penghasilan yang layak. (Pasal 88 Ayat 1)

15. Upah minimum. (Pasal 90 Ayat 1)

16. Jaminan sosial tenaga kerja. (Pasal 99 Ayat 1)

17. Hak uang pesangon. (Pasal 156 Ayat 2)

18. Hak uang penghargaan masa kerja. (Pasal 156 Ayat 3)

Kegiatan pengabdian kepada masyarakat ini ditanggapi secara positif oleh para peserta. Tanggapan positif itu dapat dilihat dari adanya respon berupa pertanyaan dari salah seorang peserta setelah tim pelaksana memaparkan materi, yaitu peserta yang bernama Basri mengajukan pertanyaan "Bagaimana cara melaporkan apabila ada perusahaan yang menggaji karyawannya di bawah UMR Kota Pekanbaru? Apakah ada sanksinya untuk perusahaan tersebut?"

Menurut Pasal 90 Ayat (1) Undang-Undang Nomor 13 Tahun 2003 tentang Ketenagakerjaan, pengusaha dilarang membayar upah lebih rendah dari upah minimum. Ketentuan ini menyatakan secara tegas bahwa perusahaan wajib membayar upah tenaga kerjanya sesuai dengan upah minimum yang berlaku di Kota Pekanbaru sesuai dengan Keputusan Gubernur Riau Nomor: Kpts.949/XI/2018 tentang Upah Minimum Kabupaten/Kota se-Provinsi Riau Tahun 2019, yaitu Rp 2.762.852,- untuk Kota Pekanbaru.

Apabila ada perusahaan di Kota Pekanbaru yang membayar upah tenaga kerjanya di bawah Upah Minimum Kota (UMK) Pekanbaru sebagaimana yang telah disebutkan di atas, maka tenaga kerja yang dirugikan tersebut dapat melaporkannya kepada Dinas Tenaga Kerja Kota Pekanbaru dengan cara membuat laporan tertulis pada Loket Pengaduan Ketenagakerjaan di kantor Dinas Tenaga Kerja Kota Pekanbaru yang beralamat di Jl. Samarinda No. 29, Pekanbaru.

Setelah memerima laporan pengaduan, pihak Dinas Tenaga Kerja Kota Pekanbaru akan segera memprosesnya dengan cara melakukan pemeriksaan ke perusahaan yang telah dilaporkan tersebut untuk mengumpulkan data dan informasi guna mencocokkannya dengan laporan pengaduan yang ada. Apabila perusahaan yang dilaporkan tersebut terbukti membayar upah tenaga kerjanya di bawah upah minimum yang telah ditetapkan oleh pemerintah, maka Dinas Tenaga Kerja Kota Pekanbaru akan memberikan Surat Peringatan agar perusahaan tersebut mematuhi peraturan yang berlaku.

Undang-Undang Nomor 13 Tahun 2003 juga menegaskan bahwa sanksi pidana bagi perusahaan yang membayar upah tenaga kerja di bawah upah minimum adalah pidana penjara paling singkat 1 (satu) tahun dan paling lama 4 (empat) tahun dan/atau 
denda paling sedikit Rp 100.000.000,- (seratus juta rupiah) dan paling banyak Rp 400.000.000,- (empat ratus juta rupiah).

Selain itu, dalam Tri Dharma perguruan tinggi, salah satu kewajiban seorang dosen adalah melaksanakan pengabdian kepada masyarakat. Oleh karena itu, kegiatan penyuluhan hukum dengan judul "Peningkatan Pemahaman Karyawan PT Asia Forestama Raya Mengenai Perlindungan Hak-hak Tenaga Kerja Kontrak Berdasarkan Undang-Undang Nomor 13 Tahun 2003 tentang Ketenagakerjaan” ini merupakan salah satu bentuk pengabdian kepada masyarakat berupa penyuluhan hukum yang dilaksanakan oleh tim pelaksana dari Fakultas Hukum Universitas Lancang Kuning.

\section{KESIMPULAN DAN SARAN}

Permasalahan mitra dalam kegiatan pengabdian kepada masyarakat ini adalah minimnya pemahaman karyawan PT Asia Forestama Raya mengenai perlindungan hakhak tenaga kerja kontrak berdasarkan Undang-Undang Nomor 13 Tahun 2003 tentang Ketenagakerjaan. Pelaksanaan kegiatan pengabdian kepada masyarakat ini manfaatnya dapat dirasakan langsung oleh para peserta, yaitu meningkatkan pemahaman karyawan PT Asia Forestama Raya mengenai perlindungan hak-hak tenaga kerja kontrak berdasarkan Undang-Undang Nomor 13 Tahun 2003 tentang Ketenagakerjaan. Hal ini dapat dilihat dari jawaban para peserta pada kuisioner yang diberikan sebelum dan setelah kegiatan dilaksanakan. Sebelum kegiatan dilaksanakan, dari 31 orang peserta, hanya $10,3 \%$ peserta yang menjawab mengetahui materi yang akan disampaikan. Sedangkan, setelah kegiatan dilaksanakan, 83,2\% peserta menjawab telah memahami materi yang disampaikan.

Pengabdian kepada masyarakat dengan tema mengenai perlindungan hak-hak tenaga kerja kontrak ini penting untuk terus dilaksanakan karena merupakan permasalahan yang selalu dihadapi oleh tenaga kerja. Sebaiknya kegiatan dengan tema ini dilaksanakan tidak hanya kepada karyawan PT Asia Forestama Raya, tetapi juga di perusahaan-perusahaan lainnyayang ada di Kota Pekanbaru.

\section{DAFTAR PUSTAKA}

[5]. Asri Wijayanti, 2014, Hukum Ketenagakerjaan Pasca Reformasi, Jakarta: Sinar Grafika.

[6]. Hardijan Rusli, 2011, Hukum Ketenagakerjaan, Bogor: Ghalia Indonesia.

[7]. Lalu Husni, 2015, Pengantar Hukum Ketenagakerjaan, Jakarta: Rajawali Pers.

[8]. R. Joni Bambang S., 2013, Hukum Ketenagakerjaan, Bandung: Pustaka Setia.

[9]. Soedarjadi, 2008, Hukum Ketenagakerjaan di Indonesia; Panduan bagi Pengusaha, Pekerja, dan Calon Pekerja, Yogyakarta: Pustaka Yustisia.

[10]. Undang-Undang Nomor 13 Tahun 2003 tentang Ketenagakerjaan. 